\title{
Cave Use Variability in Central Maluku, Eastern Indonesia
}

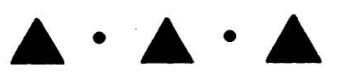

D. KYLE LATINIS AND KEN STARK

IT IS NOW INCREASINGLY CLEAR that humans systematically colonized both Wallacea and Sahul and neighboring islands from at least 40,000-50,000 years ago, their migrations probably entailing reconnoitered and planned movements and perhaps even prior resource stocking of flora and fauna that were unknown to the destinations prior to human translocation (Latinis 1999, 2000). Interestingly, much of the supporting evidence derives from palaeobotanical remains found in caves. The number of late Pleistocene and Holocene sites that have been discovered in the greater region including Wallacea and Greater Near Oceania, most of which are cave sites, has grown with increased research efforts particularly in the last few decades (Green 1991; Terrell pers. comm.). By the late Pleistocene and early Holocene, human populations had already adapted to a number of very different ecosystems (Smith and Sharp 1993).

The first key question considered in this chapter is, how did the human use of caves differ in these different ecosystems? We limit our discussion to the geographic region of central Maluku in eastern Indonesia (Fig. 1). Central Maluku is a mountainous group of moderately large and small equatorial islands dominated by limestone bedrock; there are also some smaller volcanic islands. The region is further characterized by predominantly wet, lush, tropical, and monsoon forests. Northeast Buru demonstrates some unique geology (Dickinson 2004) that is responsible for the distinctive clays and additives used in pottery production (discussed later in this paper). It is hoped that the modest contribution presented here will aid others working on addressing this question in larger and different geographic regions.

A second interest is to illustrate the extent of variation in central Malukan cave use using archaeological, ethnographic, and historical data (but concentrating on the first category; see Table 1). A third interest is to contribute to understanding whether there were limited periods of intensive migration and/or nonlocal influence followed by long periods of sparse or no migration, or a constant (albeit oscillating) stream of migration and interaction. Such questions have been central

D. Kyle Latinis, Southeast Asian Studies Program, National University of Singapore; Ken Stark, Department of Anthropology, Kwantlen University College, Vancouver, Canada 


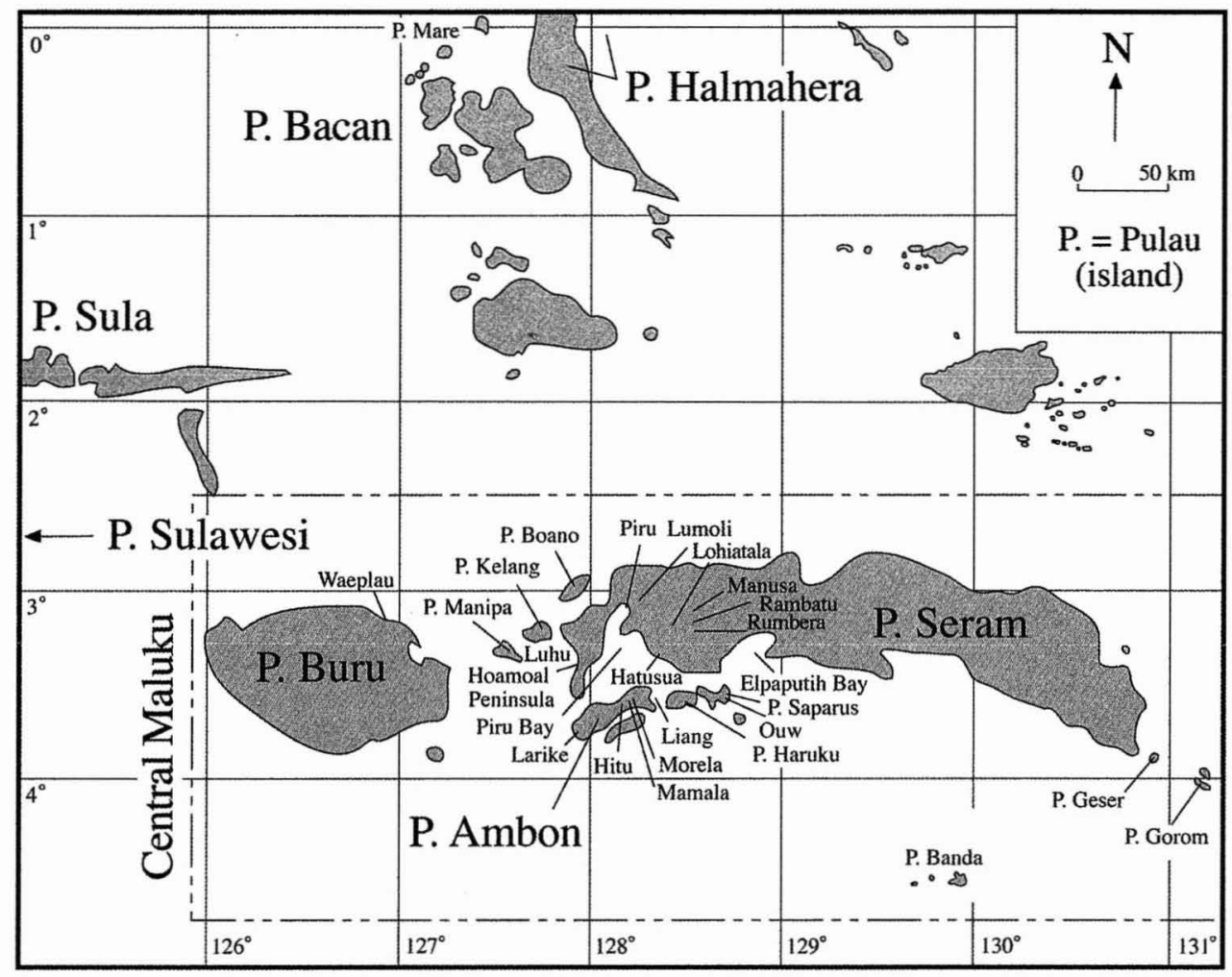

Fig. 1. Central Maluku, eastern Indonesia: place names and survey areas mentioned in the text.

to the debates about the beginnings of agriculture and arboriculture in the region and the strengths and weaknesses of the Austronesian ${ }^{1}$ colonist model (this volume: Barker et al.).

\section{MODERN ARCHAEOLOGY IN CENTRAL MALUKU}

Intensive archaeological surveying and testing were first conducted by Spriggs and Miller in the 1970s (Spriggs 1990, 1994; Spriggs and Miller 1979). They identified many cave sites including the Hatuhuran Cave Complex, which was subsequently surveyed and tested by the Hawai'i-Pattimura team in 1993 (Latinis and Stark 2003; Stark 1995). Glover and Ellen $(1975,1977)$ conducted archaeological assessments, but these concerned mainly pottery traditions, ethnoarchaeological pottery manufacture, and flaked stone tools. There was no particular emphasis on caves. An Indonesian team (Bintarti et al. 1977) conducted a cursory survey and noted a few potential cave sites. Ballard (1988a, 1988b) assessed cave/ rock art sites in the neighboring Kei islands and discusses a few known cave/rock art sites in central Maluku (Buru and Seram islands), although no intensive modern archaeological research has been undertaken at these sites.

The University of Hawai' $i$-Pattimura team conducted surveys and excavations in central Maluku, most of which involved cave sites discussed below. Finally, 
Lape (1998, 2000a, 2000b) conducted surveys and excavations in the Banda islands, although the research was not focused upon cave sites. It should be noted that a fair amount of cave research has also been conducted in neighboring regions such as northern Maluku and Sulawesi (Bellwood 1997; Glover 1981, 1986), southeastern Maluku (Bartstra 1998; O'Connor et al. 1998), and the Vogelkopf region in western Papua (Bartstra 1998).

From 1991 to 1995 Ken Stark and Kyle Latinis conducted surveys and excavations on the islands of Ambon, Buru, Saparua, and Seram, with Latinis conducting follow-up surveys and limited testing from 1995 to 1998 (Fig. 1). The latter surveys also included Gesser, Gorom, and Haruku islands. Labarisi, a moderately large rock shelter near Waeplau village on Buru, was excavated in 1993. Batususu cave near Morela village on Ambon island was tested less intensively for subsurface deposits. The data for these excavations were reported in detail by Stark (1995). Additionally, an open-air site and cave site within the Hatuhuran Cave Complex in Seram island (also known as the Batuhuran or the Hatusua sites, originally identified by Spriggs and Miller) were excavated in 1993, though published only recently (Latinis 2002a, 2002b; Latinis and Stark 2003). Several additional cave sites were identified and superficially assessed in Seram and the Leihitu peninsula on Ambon island from 1993 to 1998 by Stark and Latinis (1992, 1996), and Latinis (2002a). More than fifty caves have been explored by Latinis in the area, although only three caves have been mapped and significantly tested for subsurface archaeological remains by excavation. Many of the caves have multiple openings and undoubtedly belong to larger limestone cave systems.

\section{Buru}

Excavations at the Labarisi site revealed four stratigraphic layers, the upper two (Layers 1 and 2) containing ceramics and the lower two (Layers 3 and 4) being aceramic. All layers contain faunal remains (the initial assessment indicates mostly rat, bird, snake, lizard, mollusk, gastropod, and unidentified microfauna), botanical remains (predominantly Celtis ulmecea), and small flake stone tools and waste material composed mostly of chert, quartz, and limestone.

Initial radiocarbon dates from charcoal proved to be contaminated by the $\mathrm{Pa}-$ cific nuclear testing program of the 1950s and 1960s. Recent dates by Geochron Laboratories of marine shell samples yielded preliminary uncalibrated dates for Layer 2 of $6600 \pm 90$ B.P., and for Layer 3 of $710 \pm 50$ B.P. These dates indicate both early and more recent use. The anomalous inversion is likely the result of post-depositional disturbances (the subject of a forthcoming paper that will discuss the radiocarbon dates and stratigraphy in more detail). The mid Holocene date was not unexpected, as the aceramic assemblage and the site context are reasonably similar to many late Pleistocene and early Holocene sites in Southeast Asia and Near Oceania. It is likely that much earlier dates (perhaps late Pleistocene) will be obtained in the future.

Most of the Labarisi ceramics are a distinctive greyish blue, with high concentrations of platelike large grains of sand and rock (Dickinson 2004). One piece, a bowl, has an inverted incised rim, painted red, and fits well within the Austronesian design repertoire. Energy dispersive $\mathrm{x}$-ray fluorescence (EDXRF) testing of ceramics from a variety of sources revealed a tight cluster in the Labarisi sherds 
Table i. Brief Description of Caves Surveyed, Archaeological Remains, and Estimated Age

\begin{tabular}{|c|c|c|c|c|c|}
\hline ISLAND & $\begin{array}{l}\text { GENERAL LOCATION } \\
\text { (VILLAGE OR } \\
\text { LOCATION FROM } \\
\text { NEAREST VILLAGE) }\end{array}$ & $\begin{array}{l}\text { APPROXIMATE } \\
\text { NO. OF CAVE } \\
\text { ENTRANCES AND } \\
\text { CHAMBERS } \\
\text { EXPLORED }\end{array}$ & $\begin{array}{c}\text { DESCRIPTION OF ARCHAEOLOGICAL } \\
\text { REMAINS }\end{array}$ & ESTIMATED AGE & COMMENTS \\
\hline Ambon & $\begin{array}{l}\text { Liang (behind and } \\
\text { toward the } \\
\text { mountains) }\end{array}$ & 15 & $\begin{array}{l}\text { Approximately } 1 / 3 \text { contain surface } \\
\text { earthenware scatters, some with } \\
\text { human skeletal remains. At least two } \\
\text { caves contain WWII remains. }\end{array}$ & $\begin{array}{l}\text { Protohistoric to } \\
\text { early historic; } \\
\text { WWII }\end{array}$ & $\begin{array}{l}\text { The ceramic scatters contain many } \\
\text { red-slipped and incised sherds. }\end{array}$ \\
\hline Ambon & Amaheru & 5 & $\begin{array}{l}2 \text { caves contain surface earthenware } \\
\text { scatters, lithic tools, and faunal } \\
\text { remains; } 1 \text { separate cave contains a } \\
\text { stone wall. }\end{array}$ & $\begin{array}{l}\text { Protohistoric to } \\
\text { modern }\end{array}$ & $\begin{array}{l}\text { The ceramic scatters contain many } \\
\text { incised sherds, a net weight (?), and } \\
\text { unusual functionally unidentifiable } \\
\text { ceramic and stone artifacts. The } \\
\text { stone wall may be a WWII feature. }\end{array}$ \\
\hline Ambon & Rahban & 3 & $\begin{array}{l}\text { No surface remains in caves but nearby } \\
\text { surface artifacts - primarily pottery. }\end{array}$ & $\begin{array}{l}\text { Protohistoric to } \\
\text { early historic }\end{array}$ & $\begin{array}{l}\text { The ceramic scatters contain many red- } \\
\text { slipped sherds, nut-cracking stones, } \\
\text { and some } 12 \text { th- to } 15 \text { th-century } \\
\text { Chinese, Thai, and Vietnamese } \\
\text { ceramics. }\end{array}$ \\
\hline Ambon & Morela & 2 & $\begin{array}{l}\text { No surface remains in the caves. There } \\
\text { are stone walls in the vicinity. }\end{array}$ & Premodern & $\begin{array}{l}\text { The stone walls are almost certainly } \\
\text { not late historic. No other } \\
\text { information is known. }\end{array}$ \\
\hline Ambon & Mamala & 4 & $\begin{array}{l}\text { No surface remains in the caves. There } \\
\text { are stone walls in the vicinity. Also, } \\
\text { nut-cracking stones and anvils are } \\
\text { common in the area. }\end{array}$ & Premodern & $\begin{array}{l}\text { The stone walls are almost certainly } \\
\text { not late historic. No other } \\
\text { information is known. }\end{array}$ \\
\hline Ambon & Kapahaha & 3 & $\begin{array}{l}\text { No surface remains in the caves. Many } \\
\text { ceramics are located in the vicinity. }\end{array}$ & Historic & $\begin{array}{l}\text { Most of the ceramics are non-local } \\
\text { stonewares and glazed wares dating } \\
\text { from the } 17 \text { th-20th centuries. }\end{array}$ \\
\hline
\end{tabular}


1 cave contains surface and subsurface

\begin{tabular}{|c|c|}
\hline Ambon & Hila \\
\hline Ambon & Kaitetu \\
\hline Ambon & Hitu \\
\hline Ambon & $\begin{array}{l}\text { Tomu (behind } \\
\text { Hitu) }\end{array}$ \\
\hline Ambon & Leitimor Peninsula \\
\hline Kelang & \\
\hline Seram & Sawai \\
\hline . & \\
\hline Seram & Masihulan \\
\hline Seram & $\begin{array}{l}\text { Southwest coast of } \\
\text { the Huamoal } \\
\text { Peninsula }\end{array}$ \\
\hline Seram & $\begin{array}{l}\text { Southeast coast of } \\
\text { the Huamoul } \\
\text { Peninsula. }\end{array}$ \\
\hline Seram & Lumoli \\
\hline
\end{tabular}

No surface remains in caves noted. ceramic, lithic (mostly nut-cracking stones), faunal, and floral (mostly C. indicum) remains.

No surface remains in caves noted.

No surface remains in caves noted.

About 1/3 contain surface earthenware scatters, some with human skeletal remains. At least one cave contains WWII remains.

No surface remains in caves.

2 cave entrances/exteriors contain painted hand stencils and drawings (red).

No surface remains in caves. historic (?) stacked stone features are

Premodern

rotohistoric to historic

Modern modern $(14$ dates available)

Premedering

No surface remains in caves, but abundant.

2 caves contain surface ceramic scatters.

1 cave contains modern habitation remains.
Historic to modern (?)

Historic to modern

Modern

The upper terrace was excavated in 1993 (Stark 1995). The

earthenwares are often red slipped and compositionally related to the protohistoric Tomu site.

a

The ceramic scatters contain many red-slipped and incised sherds. Numerous nut-cracking stones are located nearby.

Evidence of modern use and rubbish disposal in many caves.

Local informants mentioned that many caves exist. Tense circumstances prevented the team from visiting. The caves with paintings are located on an inaccessible cliff and could not be properly surveyed. They likely contain artifact remains. Other caves in the mountains behind Sawai village contain no b remains.

This area was surveyed by the assistants and not by the authors.

The ceramics are earthenwares and some foreign stonewares and glazed wares. 
TABle I (Continued)

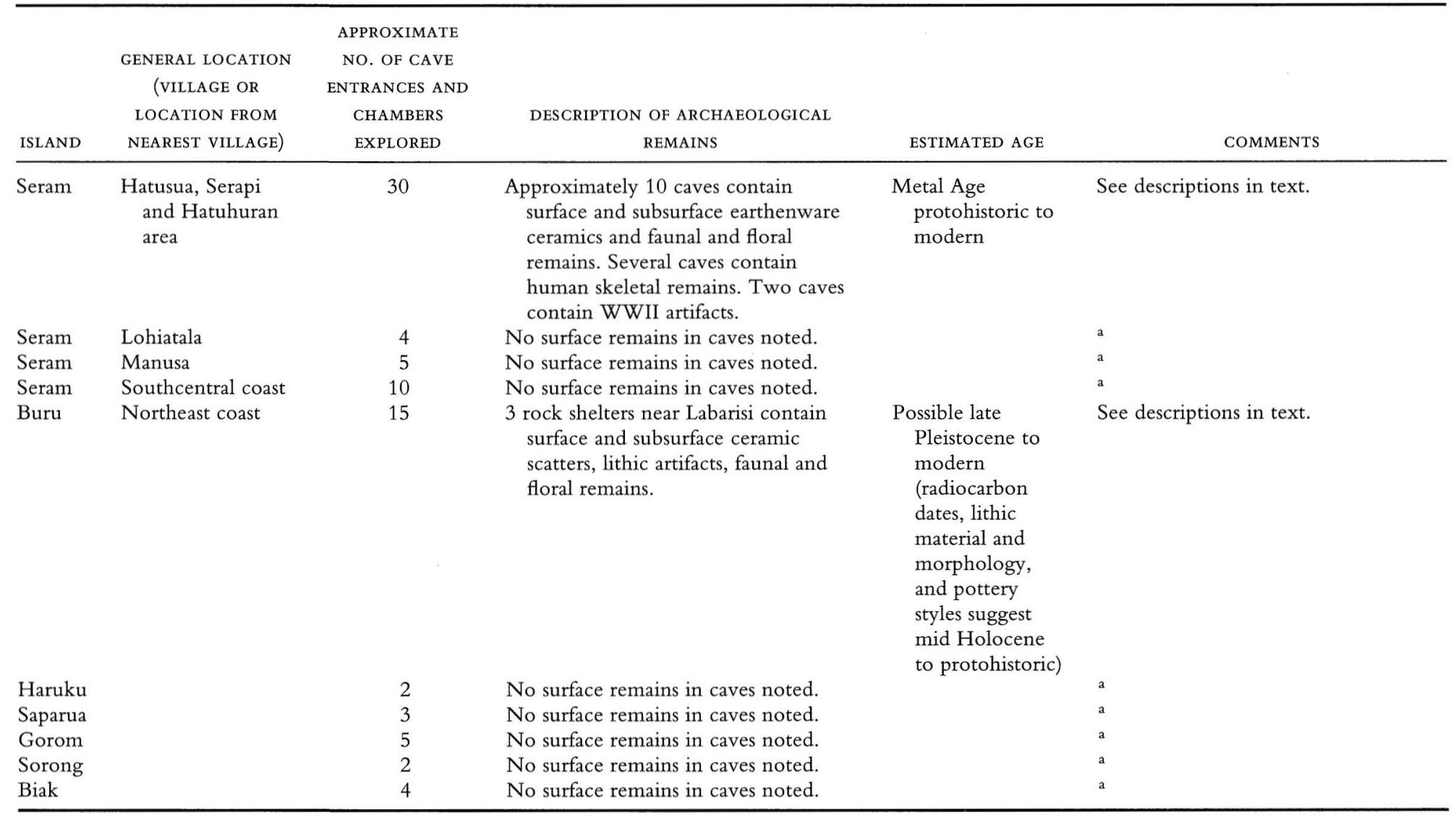


${ }^{a}$ Local informants stated that cave with ancient remains do exist. However, many that were checked did not exhibit archaeological remains or human modification but were generally associated with a local legend (e.g., a legendary person had been turned into a uniquely shaped but otherwise natural stone).

b These areas were surveyed by field assistants and not by the authors.

Notes: "Metal Age" in Central Maluku refers to a period between the late first millennium B.C. and the first millennium A.D. Protohistoric generally defines the period from around 2000 to 2500 years ago when products from Maluku are noted in Chinese documents to the fifteenth century. Others define protohistoric to the few centuries before Portuguese arrival when place names are mentioned in epic poems such as the Desawarnana. As defined earlier in the text, there is a significant degree of overlap between traditional definitions of Maluku's "Metal Age" (Bellwood 1997) and our definition of "protohistoric." Additionally, many of these settlements may not have had access to metal items or the technology while other contemporaneous settlements did. These periods are only useful constructs for current data analysis and should not be seen as definitive periods of relative cultural or material culture stability.

Most of the caves have associated myths, some of which are modern, but many are likely premodern, protohistoric, or even prehistoric.

Caves with skeletal remains are almost always associated with red-slipped and incised earthenware. Skeletal remains are generally skulls and long bones. The absence of smaller bones may suggest post-mortem translocation. However, smaller bones may have been overlooked during the rapid survey phase.

This is only a list of caves explored during the 1992-1998 University of Hawai'i, National University of Singapore, and Universitas Unpatti archaeological surveys and excavations conducted by D. Kyle Latinis and Ken Stark. Spriggs (pers. comm.) explored additional cave sites, one of which on Saparua may be quite old.

Most of the caves were rapidly explored and assessed to determine if they were worth further investigation to address Ken Stark's and D. Kyle Latinis's Ph.D. research projects. Thus, detailed note taking and mapping were not conducted except at caves that had high potential. Modern cave use outside of early historic, protohistoric, prehistoric, and WWII occupation was not a major concern of the research. Many caves near settlements exhibit modern refuse deposits. Some caves are known to be secret meeting places and rendezvous locations.

Most of the caves are part of limestone cave network systems. They have multiple openings and chambers, many of which collapse owing to the highly tectonic nature of the region. In most cases it is unknown which connect throughout as this would take kilometers of exploration and years of mapping. Also, artifact remains are found in many contiguous chambers and openings. Thus, it is difficult whether or not to classify them as separate based on the physical chamber or entrance (many chambers separated by ceiling collapse) or connected based on temporal use and similar cultural tradition. It is quite possible that different settlements used different parts of the cave system or separate chambers within a connected network of chambers.

The mid Holocene high sea levels may be a factor in cave formation, use, and archaeological deposits; the extent of which in Central Maluku is currently unknown.

Generally, artifact and skeletal remains are located near cave entrances or chambers located immediately near entrances. Chambers located at significantly long distances from an entrance almost never exhibit archaeological remains.

Again, caves should be considered part of settlement and total resource environment clusters of site types. It is doubtful that they represent the true variability of site types and material culture for any given group in the past.

Many other locales were surveyed but those without cave survey were omitted (e.g., Piru). These areas likely do contain caves. Also, areas without remains listed above may contain unexplored caves with significant archaeological remains. 


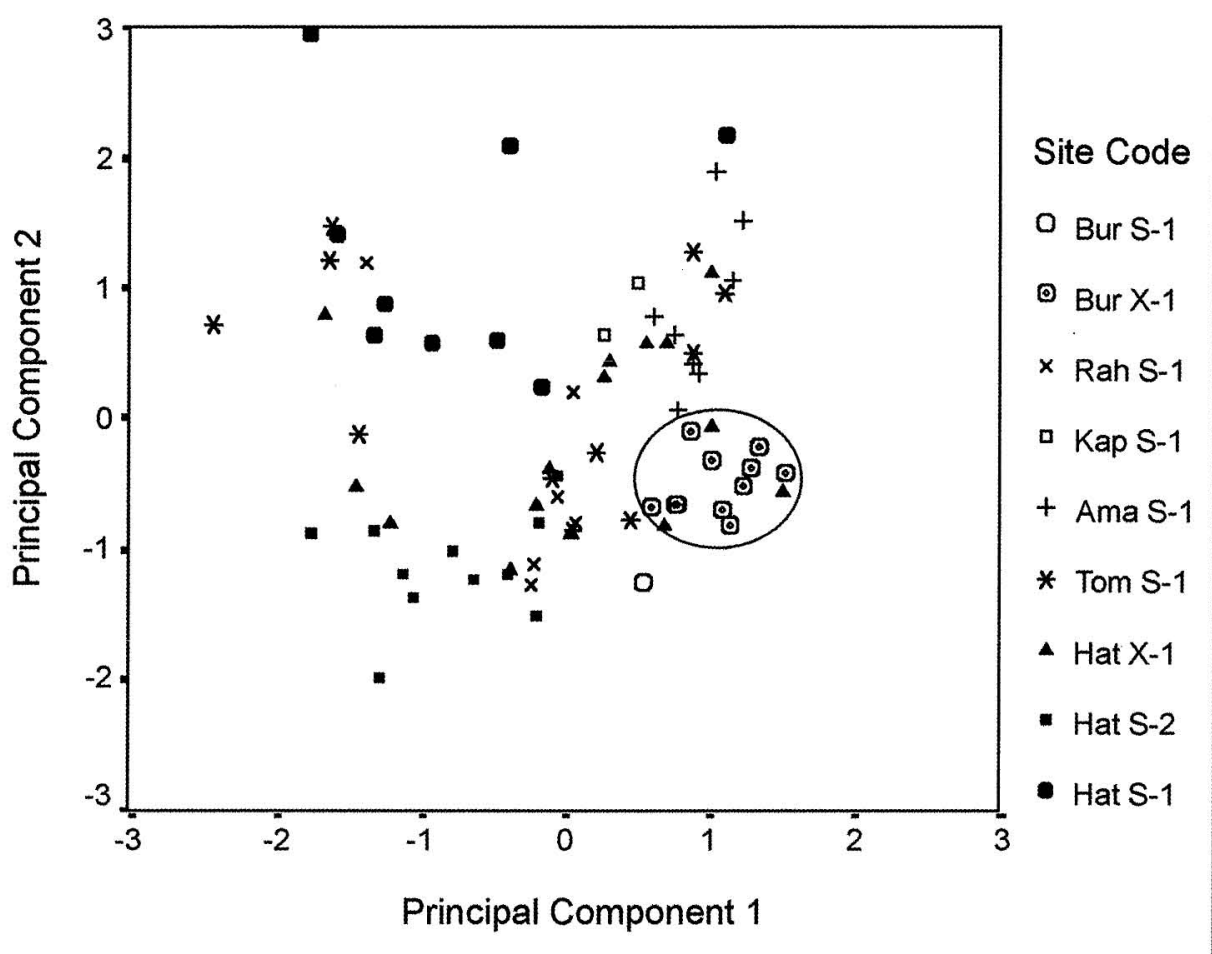

Fig. 2. Scatter plot of first two principal components from EDXRF analysis conducted on earthenware sherds from Malukan sites. Bur S-1 = Labarisi Cave site (Buru; surface samples); Bur X1 = Labarisi Cave site (Buru; excavation samples); Rah S-1 = Rahban site (Ambon; surface samples); Kap S-1 = Kapahaha site (Ambon; surface samples); Ama S-1 = Amaheru site (Ambon; surface samples); Tom S-1 = Tomu site (Ambon; surface samples); Hat X-1 = Hatusua site (Seram; excavation samples); Hat S-2 = Hatusua site (Seram; surface samples); Hat S-3 = Hatusua site (Seram; surface samples). The 15 elements that were tested include Calcium (Ca), Titanium (Ti), Manganese $(\mathrm{Mn})$, Iron (Fe), Cobalt (Co), Nickel (Ni), Copper (Cu), Zinc (Zn), Gallium (Ga), Rubidium (Rb), Strontium (Sr), Yttrium (Y), Zirconium (Zr), Niobium (Nb), and Lead ( $\mathrm{Pb}$ ).

(Fig. 2), with almost no overlap with other Malukan sites. (EDXRF analysis identifies trace elements and their concentrations in clay and temper and is used for ceramic sourcing and trade studies [Miksic and Yap 1992].) This is further corroborated by Dickinson's (2004) petrographic studies. By contrast, most ceramics tested from protohistoric central Maluku sites (excluding Gorom and eastern Seram) demonstrate considerable overlap in their EDXRF signatures, probably reflecting trade and interaction (see also Dickinson 2002 and 2004 for transfer evidence of Halmahera ceramics through northern, central, and southeastern Maluku). The Labarisi ceramics do not appear to demonstrate ceramic import or multiple ceramic sources. ${ }^{2}$

The radiocarbon date of $710 \pm 50$ в.P. from Labarisi overlaps with the estimated eighth- to fifteenth-century dates for many of the Seram and Ambon protohistoric sites and the dates obtained from the Seram and Ambon sites discussed below. However, given their differences with the pottery of other central Malukan sites (the pottery of which is characteristically red, brown, and occasionally 
buff with finer grained and less dense inclusions, and frequently slipped, painted, burnished, and incised), it remains possible that the Labarisi ceramics are temporally distinct as well, and perhaps considerably older. It could be that Labarisi was simply excluded from larger or extralocal trade spheres. Additionally, it should be noted that Sapurua pottery, which dominates recent historic and modern westcentral Maluku, generally has a characteristic forminera marl and additive composition that is absent in most archaeological samples considered in this study.

\section{Ambon}

Ambon has been surveyed much more intensively. The northern coast of the Leihitu Peninsula is dominated by many limestone formations with numerous caves as well as less obvious volcanic formations indicated by andesitic rock in many streambeds and andesitic stone tools in many sites. Numerous protohistoric and historic sites are located along the north coast (Latinis and Stark 2003; Spriggs 1990; Stark 1995). Many of the protohistoric sites occur in defensive locations on hillslopes or hilltops, often with large surrounding walls. Almost all have extensive surface scatters of red and brown earthenware, a good portion of which is incised, red-slipped, burnished, and sometimes painted. A small percentage (usually ca. 12 percent maximum) of Chinese, Thai, and Vietnamese stoneware and porcelain helps place terminal occupation dates in the thirteenth to fifteenth centuries. Almost all of these sites have limestone caves nearby containing earthenware scatters, and several caves also contain human remains. Most of the cave sites are damp, cramped, dangerous (e.g., prone to collapse from tectonic activity), and filled with bat guano and other unattractive faunal and floral elements, and have low ceilings and low or zero light levels, making it highly unlikely that they were used for habitation, except perhaps only of a temporary nature (with the exception of the permanent residence of the dead). The surveyed caves yielded no signs of long-term habitation.

Most locals assume that many of the human remains are those of victims of World War II and more recent conflicts. However, those more familiar with local folklore suggest that the remains were placed during the jaman perang suku, "ethnic" wars of ancient times. It is often unclear whether the use of this term refers to the precolonial or early colonial period, or possibly to both. However, the conflicts with the Portuguese and Dutch are often locally referred to as colonial wars. It is possible that the term "jaman perang suku" generally reflects precolonial strife. This is further supported by folklore related to the Tomu and Hatusua sites that likely has its roots in precolonial times.

Preliminary observations indicate that the human remains generally consist of skulls and long bones, with a notable absence of smaller bones such as phalanges. This may indicate secondary burial practices in caves, not uncommon in Island Southeast Asia. Additionally, the remains were almost always noted in conjunction with earthenware scatters, perhaps indicative of jar burial practice (again, not uncommon in Island Southeast Asia), although no bones were actually found in jars. In fact, no complete jars were observed, reminding us of the observation by Bellwood (1997:297) that the jars in the burial site of Leang Buidane in northeastern Indonesia "were originally placed on the floor of the cave, but were smashed - presumably deliberately-in antiquity." 
The Batususu site excavated by the Hawai'i-Pattimura team is a limestone cave formed from a stream cut in the center of the outcrop on the forested mountain slopes behind Morela. Earthenware surface scatters were noted on either side of the embankments. Excavations produced an assemblage of earthenware ceramics, numerous andesite and limestone nut-cracking stones and anvils, Canarium indicum nut remains, some shell remains, and some faunal remains including a fairly complete megapode, but no human remains. C. indicum, high in fat, protein, and calories, is an important food staple for the present population, and is also a preferred shade tree for growing pala (nutmeg, Myristica fragrans). This could be an indicator that significant nutmeg production occurred nearby in historic and protohistoric times. Additionally, an increase in Canarium size over time may reflect human selection and manipulation (Stark 1995).

Uncalibrated radiocarbon dates from the site include $320 \pm 70$ B.P. (Beta73696) for Layer 2, $350 \pm 50$ B.P. (Beta-73694) for Layer 3, and 170 B.P. (note that there were sampling problems that cannot be adjusted at the present time [Beta-73695]) and $780 \pm 60$ B.P. (Beta 73693) for Layer 4 (Stark 1995). The anomalous date is likely to be intrusive material or a selection error. Basal deposits were not reached owing to blockage by extensive tree roots (which may have also pushed the aberrant sample into lower deposits). Earthenware ceramics from Layer 4 match samples from the walled protohistoric Tomu site near Hitu village, which has a terminal occupation date probably around the thirteenth to sixteenth centuries. Again, the dates are based on the occurrence of Chinese, Vietnamese, and Thai ceramics present in surface scatters dating to that temporal range.

Interestingly, the Tomu site has literally thousands of nut-cracking anvil and hammer stones, perhaps indicating a significant $C$. indicum-processing industry, or a significant nutmeg and $C$. indicum industry, in the northern Leihitu peninsula. Nutmeg and mace were certainly extremely important trade commodities during the first and second millennia A.D. During late protohistoric and early historic times, however, Banda (a spice trade node for nutmeg and mace) managed to monopolize production, although it is possible that it received shipments from other islands such as Ambon (see Ellen 2003 for further details on central Maluku and trade in the protohistoric and historic periods). The Batususu site, not a particularly comfortable place to inhabit, may have been a rest stop and work station for processing $C$. indicum. Batususu is also about midway to Kapahaha, a famous fortified mountain retreat where Hitu (at that time a federation of villages, including Tomu) fought decisive battles with the early colonial Dutch.

\section{Seram}

Several sites were identified in the Piru Bay and hinterland region of southwestern Seram. The most extensive was the Hatusua site. The site, originally identified by Spriggs (1990) as the Hatuhuran cave complex, has now revealed itself to be a large walled hillslope and coastal protohistoric settlement with numerous limestone cave sites, both coastal and inland. Other sites include cave sites, openair village sites (likely historic, but possibly protohistoric), a rock painting cliff/ cave site in Sawai (north Seram), and other sites with legends attached to them but no noticeable archaeological remains. One rock overhang site near Lumoli in the mountainous hinterlands behind Piru is still in use, with a wooden bed 
platform. It is said to be the resident of an eccentric old man and is probably his forest walang (a local term meaning forest hut, house, rest area, or processing station).

The few rock art sites checked in Sawai displayed red hand stencils, not uncommon in Island Southeast Asian limestone cave sites. The dating of these sites is difficult. They might predate Austronesian influence, or they could be much more recent. Whether or not the tradition remained continuous over a long period of time or was periodically revived is difficult to determine. Many similar sites have artifact deposits, but relating the latter to the cave paintings is difficult. Nevertheless, it should be noted that a cave art tradition is present in central Maluku and that many of the cave sites are visible from the sea, the paintings being located on terraces, cliff faces, and cave entrances near the coast (see Ballard 1988a, 1988b for detailed discussions and interpretations).

The numerous cave sites in the Hatuhuran cave complex and adjoining Hatusua site frequently contain earthenware scatters and combined earthenware and human bone scatters. Occasionally some caves show signs of recent use, though locals tend to fear and avoid the caves, especially the Hatuhuran area during the night (it is said that witches and ancient spirits of wrongfully killed royalty haunt the area, sometimes with fatal results). The sites with human remains generally contain skulls and long bones, possibly indicating secondary burials. Although many broken jars were observed, no jar burials were noted. Again, jars may have been broken intentionally in antiquity (Bellwood 1997). Vessel morphology, designs, composition, and overall context all indicate a protohistoric Austronesian tradition identical to that of the northern Leihitu Peninsula on Ambon. However, some designs may indicate influence from an earlier and broader Metal Age tradition, sharing general affinities with material from eastern, central, and western Indonesia, the Philippines, and perhaps other Austronesian groups elsewhere (e.g., Near Oceania).

Excavations at the site in 1993 included a $3 \times 3 \mathrm{~m}$ unit in the open area, a trench leading up to a cave, and several test pits within the cave (approximately $25 \mathrm{~m}^{2}$ were excavated). The latter yielded the lowest density of artifacts, but included some human remains (a mandible fragment and some teeth). The most ubiquitous artifacts are earthenware ceramics, many of which are incised, redslipped, lightly burnished, and, less frequently, painted. Most belong to six types: restricted and unrestricted jars; platters or shallow bowls; plain bowls or cups with ring feet; basally incised (on the upper surface only) dishes or bowls with ring feet; incised and decorated tungku (iron-shaped lugged earthenware stoves common in Southeast Asia); and burnished oil lamps with pinched spouts. The first five are typical of many surface scatters on Ambon, but the latter is not. Whether or not this indicates that the cave areas, especially proximate to entrances, were used for ritual purposes is unknown, although it remains a possibility: the extensive decorations on the stoves and dishes may indicate that they were used for ritual activities including offerings of food or other items.

Other artifacts included some made from shell and faunal remains, a few pieces of iron and bronze, three stoneware fragments (most likely thirteenth- to fourteenth-century Chinese storage vessels), small stone disks (possibly gacuk-a type of token), and one blue triangular sectioned glass bangle fragment, probably of Chinese origin. Surface scatters outside the caves, like protohistoric sites on 
Ambon, contain a small percentage of thirteenth- to fifteenth-century Thai, Vietnamese, and Chinese ceramics, possibly indicating a terminal occupation date.

Two radiocarbon dates from lower ceramic-bearing deposits from a trench just outside the Hatusua cave site indicate an initial occupation as early as the eighth century: 2 sigma calibrated result A.D. 775-980 (Beta-181923, conventional $1160 \pm 40$ B.P.) and 2 sigma calibrated result A.D. 765-970 (Beta-181924, conventional $1180 \pm 40$ B.P.). It is possible that the use of these caves for burials and other activities occurred throughout the entire occupation sequence of Hatusua, intermittently or only during early or late phases. The cave excavation data are ambiguous on that matter. Ceramic designs and morphology from cave samples (including unexcavated caves) are generally similar to those analyzed from both lower level and surface collections excavated outside of the cave entrance as well as surface collections elsewhere. The similarities with the Tomu assemblage may suggest the same time span for occupation and cave use.

\section{HISTORICAL AND ETHNOGRAPHIC INFORMATION}

There is only limited historical and ethnographic information on cave use in central Maluku: mentions (often brief) in travelers' descriptions, residents' documents, colonial documents, local folklore, and, more recently, accounts from ethnographers and other researchers (Hagen pers. comm.; Latinis 1999). Few if any studies have focused specifically on cave use, with the exception of the few archaeological surveys. Though it is beyond the scope of this paper to provide lengthy details of the historic, oral historic, and ethnographic information, it should be noted that certain cave uses not revealed in the archaeological record thus far include such activities as harvesting highly valued bird nests (as a food or medicinal ingredient), ${ }^{3}$ occasional bat hunting, ${ }^{4}$ and guano collection. The antiquity of these practices remains unknown. Caves have also been used occasionally as hideouts, rest stops, recreational areas, hiding places for valuables, and sometimes garbage dumps. As previously mentioned, caves are generally feared and avoided by most Malukans.

Many caves have legends and folklore attached to them. Several limestone formations within and outside of caves are thought to be former heroes, heroines, or antiheroes who have been turned into stone by magical forces or witchcraft. Some caves are thought to harbor dangerous spirits, witches, or practitioners of black magic, the latter role resulting in unique artifacts characteristic of such practitioners. Thus, caves also serve a cultural and symbolic purpose in tandem with oral history, folklore, legend, and other beliefs that are still deeply imbedded in Malukan adat (custom, tradition, culture and the belief system generally said to be separate from agama, religion). Lastly, caves were used during the World War II period and the Repulik Maluku Selatan (RMS) conflicts as military installations and hideouts (by both locals and nonlocals). It is likely that many caves have been used as temporary, and possibly permanent, hideouts throughout Maluku's history.

\section{DISCUSSION}

In this paper, we have attempted to assess the variability of cave use in central Maluku using archaeological evidence, and, to a lesser degree, historical and eth- 
nographic data. As we have demonstrated, the evidence indicates significant variability in the uses of caves. Caves have been and are used for temporary habitation (generally short-term rather than seasonal); perhaps permanent habitation in a few locations (e.g., Labarisi), although this does not appear to be a common occurrence; burials; possible ritual locations; processing stations; sources for food as well as fertilizer and other valued economic commodities; rest stops and temporary shelters; waste disposal; recreation; artists' "canvases," perhaps even signaling and cultural learning locales; hideouts; military purposes; sources or essential parts of folklore; and possible residences of black magic specialists, witches, and so on. It is likely that other uses occur or have occurred in the past, such as meditation. There is, for example, an oral historical account of one of the founders of Hitu who meditated in the forest, perhaps in a cave. It is also likely that a single cave may have experienced several of these different uses simultaneously and/or sequentially. Discerning their archaeological signatures is possible, although some obvious difficulties exist.

In the wet, tropically forested coastal and mountainous areas of central Maluku, caves are virtually unused for habitation, either long-term or even seasonal. Most of the cave sites are not suitable for normal habitation, being very uncomfortable and quite dangerous. Central Malukans prefer to live in houses or walang in the forest. Walang are quickly assembled, far more comfortable, and safer for many reasons. Central Maluku is a tectonically active region that experiences several earthquakes each year. Indeed, some of the caves surveyed in the early 1990s had collapsed by the time of the 1997-1998 field excursions, likely owing to increased erosion and tectonic activity. Not surprisingly, caves are not likely used for permanent or seasonal habitation. Also, in some cases it is possible that only the entrance or a partial section of the cave has collapsed. This may skew interpretations if archaeological remains that were once near an opening appear to be deposited deep in the cave's interior. At least one case of this behind Liang is likely, where human remains and pottery were found over $150 \mathrm{~m}$ into the cave's interior in a lightless, cramped chamber. We suspect that a nearby entrance had collapsed.

By contrast, the Labarisi site's evidence may indicate long-term habitation, possibly permanent, but it is noteworthy that this cave is located in an unusually dry and bushlike or savannalike environment. It is possible that the use of caves for habitation varies between different environments and ecosystems, perhaps reflecting the overall wetness or dryness of the locality as well as the local distribution of resources. Labarisi also has a unique geological history and may be less prone to dangers such as erosion and tectonic activity, although there is evidence of several events of large ceiling falls.

Labarisi may indicate that aceramic groups, presumably earlier populations, may have targeted caves and rock shelters in certain environments for habitation and local resource extraction, possibly reflecting a late Pleistocene and early to mid Holocene non-Austronesian pattern. However, Labarisi also contains upper deposits with ceramics that stylistically fit within the Austronesian repertoire.

The difficult questions to answer with the current data are whether or not cave use changed through time, and how cultural differences and influences in cave use (if any) are determined. The Labarisi site has the highest potential to answer such questions. The shift from aceramic to ceramic material culture there might be interpreted in terms of the arrival of Austronesian groups, and/or the adoption of 
pottery by the existing population, and/or the use of the cave by a mixture of locals and Austronesians. Whether or not the ceramics represent incoming Austronesians, it is striking that the lithic tools and food remains in the aceramic and ceramic layers do not indicate any significant change through time. It is also evident from ceramic analysis that the Labarisi community did not trade pottery with other central Malukan groups. Neither was the site associated with a larger openair settlement within close proximity (in both respects unlike probable eighth- to fifteenth-century sites in Ambon and Seram), suggesting a level of social autonomy and isolation.

The use of caves for burials is not strictly an Austronesian phenomenon. Some cave sites in Southeast Asia have pre-Austronesian burials. However, it is interesting that jar burials and cave burials, most of which appear to be secondary, do seem to correlate in Island Southeast Asia with Austronesian material culture, so perhaps by extension with Austronesian-linked or -derived cultural groups. How much immigrant influence stimulated developments in local cave use for burials remains unknown. It could be that local practices were adopted by migrant groups, but it seems that all caves with human remains have Austronesianlike pottery.

The cave burials in central Maluku range in age from perhaps as early as the Metal Age to the protohistoric period (from roughly 2000 B.P. to the early sixteenth century). The archaeological deposits of most cave sites assessed thus far probably do not significantly predate the eighth to early sixteenth centuries. Austronesians, though, are thought to have arrived much earlier, according to linguistic models and characteristic material culture. Lape's work in Banda (Lape 2000 a) uncovered 3000-year-old sherds that probably indicate early or close to initial Austronesian influence. The present data would appear to suggest that the significant cultural shift in the use of caves for burials, as well as in how the burials were treated, took place in the protohistoric period, not necessarily coinciding with initial Austronesian arrival. These sites are frequently associated with walled, open-air protohistoric settlements on hilltops or hillslopes, so it is possible that the changes in cave use were also associated with changes in settlement.

It is possible that the immigration and influence of new social groups (new migrants, not the original Austronesian descendant migrants) and/or their ideas also brought about other changes. The Hikayat Tanah Hitu (Manusama 1977; Miksic n.d.), whose early chapters relate the fourteenth- to sixteenthcentury founding of Hitu and the subsequent formation of a federation of villages, suggests the presence of four founding families from Halmahera, Gorom, Java, and Seram. Whether such oral traditions are completely true or part myth, they clearly indicate that non-Ambonese groups were founding new settlements prior to the sixteenth century and at least as early as the fourteenth century. It is quite possible that the changes in cave use and settlement described previously were at least partially influenced by new migrant groups (both Austronesian descendents and possibly non-Austronesian descendants). They also coincide with the period when trade, shipping, and the demand for Malukan spices increased dramatically, a period that began at least 2000 years ago but that seriously affected Maluku in the early second millennium A.D. However, the present data have sobering limitations and more thorough work needs to be conducted before any reliable conclusions can be drawn. 
Ceramics occur frequently in and near the protohistoric caves, both with and without human remains. Many of the pieces are highly decorated and include many different forms, including ring-footed dishes, oil lamps, and tungku (ceramic ovens), and may indicate ritual activities in and near cave sites. The ceramics may indicate jar burials or offerings and grave goods for the deceased, which interestingly was a widespread practice especially moving north to the Philippines (Fox 1970). The ceramics from both the cave sites and the associated open-air sites in Hatusua and the northern Leihitu Peninsula also demonstrate stylistic, morphological, and compositional similarities. This feature suggests a significant degree of cultural interaction, possibly an exchange network, in the Piru Bay and Leihitu region (see Ellen 1990, 2003 for details on historic central Malukan trade networks that corroborate a possible west Seram-Piru Bay-Leihitu trade sphere). Settlement patterns seem similar as well. The evidence suggests an increasing involvement by central Maluku in Southeast Asian commerce and exchange.

\section{CONCLUSION}

Our studies emphasize the varied and changing use of caves in central Maluku, though we lack conclusive support for the wider questions posed by this evidence. We have attempted to identify environmental, historic, and cultural/social factors, the latter including migration, interaction, replacement, and possibly avoidance, in order to understand the variability, continuity, and changes in cave use. We hope that this study will encourage further interest into researching caves in order to address the kinds of questions we have posed above, and in turn stimulate new questions about the broader implications of the variability in cave records that can be addressed with archaeological, historic, and ethnographic data.

\section{NOTES}

1. The term "Austronesian" in this paper is defined by (1) a unique material culture, primarily consisting of tools, ornaments, and pottery; (2) design elements such as pottery designs, carvings, and tattoos; (3) a highly developed maritime technology; (4) a characteristic subsistence repertoire including pigs, dogs, chickens, and some translocated plant species; (5) characteristic settlement patterns; and (6) language affiliation to the Austronesian language nexus. See Bellwood (1997) for detailed discussions. Whether or not the appearance of the above traits necessarily coincided with the migration of specific ethnic groups is unclear, especially in Maluku. Select elements may have been borrowed/imported and reworked. Also, two-way transfer is likely, as well as hybridization (e.g., subsistence economies in Wallacea and Greater Near Oceania). It is our opinion that pre-Austronesian populations as well as Austronesian populations (1) actively altered and adapted a landscape to their needs in addition to adapting to the new environment, (2) had the ability to overcome water barriers, and (3) exploited a variety of terrestrial and marine environments (see Latinis 1999).

2. The Labarisi sherds form a tight and somewhat separate cluster, indicating a high chance that they come from a single different geological source (confirmed by Dickinson 2004). This corroborates conclusions drawn from the visual assessments. It is interesting that three of the Hat X-1 sherds fall in this cluster, however. It is possible that the earlier settlement of Hatusua received pottery from sites near or at Labarisi or from potters using clays and additives with a similar elemental signature. This should be explored more thoroughly before any definitive conclusions are drawn. Other sampling tests generally show a high degree of separation between the Hatusua sherds and the Labarisi sherds. The higher variability in the samples from the Hatusua and Tomu sites probably suggests a fair amount of trade and exchange (also confirmed by Dickinson 2002, 2004) and multiple clay sources.

3. These properties are generally more highly valued by the Chinese than the Malukans.

4. However, fruit bats are frequently hunted with traps or nets during their evening feed in the 
trees, rather than inside the caves during the day hours. Nevertheless, bats are occasionally hunted during the day hours in caves.

\section{REFERENCES CITED}

Ballard, C.

1988a An Austronesian rock art tradition in Western Melanesia? Paper presented at the First AURA Congress, 1988, Darwin Australia.

$1988 b$ Dudumahan: A rock art site on Kai Kecil, southeast Moluccas. Bulletin of the Indo-Pacific Prehistory Association 8:139-161.

Bartstra, Gert-Jan, ed.

1998 Bird's Head Approaches: Irian Jaya Studies-A Program for Interdisciplinary Research. Special volume of Modern Quaternary Research in Southeast Asia 15. Rotterdam: A. A. Balkema.

Bellwood, Peter

1997 Prehistory of the Indo-Malaysian Archipelago. Honolulu: University of Hawai' ${ }^{\top}$ Press.

Bintarti, D. D., J. Indraningsih, and S. Kosasih

1977 Laporan hasil survai kepurbakalaan di dearah Maluku Tengah (Pulau Ambon, Seram dan sekitarnya). Berita Penelitian Arkeologi 8. Pusat Penelitian Purbakala dan Peninggalan Nasional Departemen P \& K.

Dickinson, B.

2002 Petrography of sand tempers in modern and prehistoric potsherds and ceramic raw materials from Maluku Tengah (Central Molucca Islands), Indonesia. Petrographic Report WRD-223.

2004 Petrography of temper sands in sherds from Buru and Gorom. Petrographic Report WRD-232.

ELLen, Roy F.

1990 Trade, environment and the reproduction of local systems in the Moluccas, in The Ecosystem Approach in Anthropology: From Concept to Practice: 191-227, ed. E. Moran. Ann Arbor: University of Michigan Press.

2003 On the Edge of the Banda Zone: Past and Present in the Social Organization of a Moluccan Trading Network. Honolulu: University of Hawai'i Press.

Fox, ROBERT B

1970 The Tabon Caves. Monograph 1. Manila: National Museum of the Philippines.

Glover, IAN C.

1981 Leang Burung 2: An Upper Palaeolithic rock shelter in south Sulawesi, Indonesia. Modern Quaternary Research in Southeast Asia 6:1-38.

1986 Archaeology in Eastern Timor. Terra Australis 11. Canberra: Australian National University, Research School of Pacific Studies.

Glover, IAN C., and Roy F. Ellen

1975 Ethnographic and archaeological aspects of a flaked stone collection from Seram, eastern Indonesia. Asian Perspectives 18(1):51-61.

1977 A further note on flaked stone material from Seram, eastern Indonesia. Asian Perspectives $20(2): 236-240$.

Green, Roger C

1991 Near and Remote Oceania: Disestablishing 'Melanesia' in culture history, in Man and a Half: Essays in Pacific Anthropology and Ethnobiology in Honour of Ralph Bulmer: 491-502, ed. A. Pawley. Auckland: The Polynesian Society.

Lape, Peter

1998 Settlement, trade, and subsistence in late pre-colonial (13th-17th C) Banda Islands, Maluku, Indonesia. Paper presented at the Sixteenth Indo-Pacific Prehistory Association Congress. 1-8 July 1998, Melaka. Also see Bulletin of the Indo-Pacific Prehistory Association $17: 49$.

$2000 a$ Contact and Conflict in the Banda Islands, Eastern Indonesia 11th-17th Centuries. Ph.D. diss. Brown University, Providence, Rhode Island.

$2000 \mathrm{~b}$ Political dynamics and religious change in the late pre-colonial Banda Islands. World Archaeology 32(1): 138-155. 
LATINis, D. KyLE

1999 Subsistence System Diversification in Southeast Asian and the Pacific: Where does Maluku Fit? Ph.D. diss. University of Hawai'i, Honolulu.

2000 The development of subsistence system models for Island Southeast Asia and Near Oceania: The nature and role of arboriculture and arboreal-based economies. World Archaeology 32(1):41-67.

$2002 a$ Settlement patterns in protohistoric Maluku, eastern Indonesia. Paper presented at the seventeenth congress of the Indo-Pacific Prehistory Association, 9-15 September 2002, Academia Sinica, Taipei.

$2002 b$ Morphological, stylistic and compositional analyses of eastern Indonesian earthenware ceramics. Paper presented at the seventeenth congress of the Indo-Pacific Prehistory Association, 9-15 September 2002, Academia Sinica, Taipei.

Latinis, D. Kyle, and Ken Stark

2003 Roasted dirt: Assessing earthenware assemblages from sites in Central Maluku, Indonesia, in Earthenware in Southeast Asia: 103-125, ed. J. Miksic. Singapore: Singapore University Press.

Manusama, Z. J.

1977 Hikayat Tanah Hitu. Ph.D. diss. University of Leiden, Leiden.

Miksic, John N.

n.d. Hikayat Tanah Hitu. Unpublished manuscript (translated into English from the Malay version).

Miksic, John N., and Yap Choon TeCK

1992 Compositional analysis of pottery from Kota Cina, north Sumatra: Implications for regional trade during the twelfth to fourteenth centuries A.D. Asian Perspectives 31(1):5776.

O’Connor, Sue, Matthew Spriggs, and Peter Veth

1998 Recent results from Lemdubu Cave, the Aru Islands, Maluku, Indonesia. Paper presented at the sixteenth Indo-Pacific Prehistory Association Congress, 1-8 July 1998, Melaka. Also see Bulletin of the Indo-Pacific Prehistory Association 17:58.

Smith, M. A., AND N. D. Sharp

1993 Pleistocene sites in Australia, New Guinea, and Island Melanesia: Geographic and temporal structure of the archaeological record, in Sahul in Review: Pleistocene Archaeology in Australia, New Guinea, and Island Melanesia: 37-58, ed. M. A. Smith, M. Spriggs, and B. Frankhauser. Occasional Papers in Prehistory 24. Canberra: Australian National University, Research School of Pacific Prehistory.

Spriggs, MatThew

1990 Archaeological and ethnoarchaeological research in Maluku 1975 and 1977: An unfinished story. Cakalele $1: 47-60$.

1994 Research questions in Malukan archaeology. Typescript and paper presented at the third International Maluku Research Conference. 4-9 July 1994. Ambon: Universitas Pattimura.

Spriggs, Matthew, and D.M.S. Miller

1979 Ambon-Lease: A study of contemporary pottery making and its archaeological relevance, in Pottery and the Archaeologist: 25-34, ed. M. Millett. Occasional Publication 5. London: Institute of Archaeology.

STARK, Ken

1995 Alternative Rainforest Economies of Maluku, Indonesia: A Reply to the "Wild Yam Hypothesis" from the Archaeological Record. Ph.D. diss. University of Hawai' $i$, Honolulu.

Stark, Ken, and D. Kyle Latinis

1992 The archaeology of sago economies in central Maluku: An initial sketch. Cakalele 3:6986.

1996 The response of early Ambonese foragers to the Maluku spice trade: The archaeological evidence. Cakalele 7:51-67.

\section{ABSTRACT}

This paper explores variability in cave use in central Maluku from initial settlement in the late Pleistocene to the ethnographic present. Significant variability exists. His- 
toric and ethnographic accounts highlight cave use that is not often considered by archaeologists. Some uses may leave few archaeological signatures. Factors affecting different cave uses are examined, including environmental, social/cultural, and historical factors. The effects of immigrant population influences, such as the Austronesian immigration into and/or influence on central Maluku, are also important considerations. The possibility of multiple migrations of pre-Austronesians and various Austronesian groups, and the subsequent effects on cave use, are also discussed. Archaeological case studies include the Labarisi site (north Buru), the Hatusua site (southwest Seram), and several cave sites on the northern Leihitu Peninsula (Ambon). KeYwords: central Maluku, pre-Austronesian, Austronesian. 